\title{
Article
}

\section{Social Capital and Loan Cost: The Role of Interpersonal Trust}

\author{
Leonardo Becchetti ${ }^{1,2}$, Stefano Manfredonia ${ }^{1}$ and Fabio Pisani ${ }^{1, *}$ \\ 1 Department of Economics and Finance, University of Rome Tor Vergata, 00133 Roma, Italy; \\ becchetti@economia.uniroma2.it (L.B.); stefano.manfredonia1994@gmail.com (S.M.) \\ 2 School of Finance and Management, SOAS University of London, London WC1H 0XG, UK \\ * Correspondence: fabio.pisani@uniroma2.it
}

check for

updates

Citation: Becchetti, L.; Manfredonia, S.; Pisani, F. Social Capital and Loan Cost: The Role of Interpersonal Trust. Sustainability 2022, 14, 1238. https:// doi.org/10.3390/su14031238

Academic Editor: Olaf Weber

Received: 3 December 2021

Accepted: 18 January 2022

Published: 22 January 2022

Publisher's Note: MDPI stays neutral with regard to jurisdictional claims in published maps and institutional affiliations.

Copyright: () 2022 by the authors. Licensee MDPI, Basel, Switzerland. This article is an open access article distributed under the terms and conditions of the Creative Commons Attribution (CC BY) license (https:// creativecommons.org/licenses/by/ $4.0 /)$.

\begin{abstract}
We argue that social dilemmas structured as investment trust games are a dominant feature in social and economic life due to asymmetric information, incomplete contracts and non-overlapping competencies that are typical characteristics of business relationships. We therefore consider that borrowers living in geographical areas with higher interpersonal trust are more likely to overcome the coordination failures typical of this kind of social dilemmas, thereby creating higher economic value and reducing the risk of their economic activity. Our empirical findings support this hypothesis, showing that lenders charge significantly lower loan costs on borrowers living in areas characterized by higher interpersonal trust.
\end{abstract}

Keywords: social dilemmas; trust games; interpersonal trust; all-in spread

\section{Introduction}

Trust is the investor's willingness to make herself vulnerable to others' action. [1]

"An individual (let's call her the trustor or investor) trusts if she voluntarily places resources at disposal of another party (the trustees) without any legal commitment from the latter". [2]

Asymmetric information, incomplete contracts and non-overlapping competencies are three typical ingredients of most social and business relationships. In one of his most famous quotes, David Hume, the Scottish philosopher, argues that these conditions may create a typical social dilemma, leading to cooperation failure and suboptimal outcomes. "Your corn is ripe to-day; mine will be so tomorrow. It is profitable for us both, that I should labour with you to-day, and that you should aid me to-morrow. I have no kindness for you, and know you have as little for me. I will not, therefore, take any pains upon your account; and should I labour with you upon my own account, in expectation of a return, I know I should be disappointed, and that I should in vain depend upon your gratitude. Here then I leave you to labour alone: You treat me in the same manner. The seasons change; and both of us lose our harvests for want of mutual confidence and security." (Hume Treatise on Human Nature, 1740, book III).

The game theoretical literature has built some well-known games around these dilemmas (i.e., the Prisoner's dilemma, the Centipede game, the Trust Investment game, etc.). In the Trust Investment game [3] players act sequentially and a first mover (the trustor) chooses whether to share or not part of her endowment with a second player (trustee). The amount transferred by the trustor is multiplied by three. The trustee has the second and final move in the one shot version of the game, where she has to decide whether to give back or not part of what received by the trustor. The Nash equilibrium of the game when purely self-regarding preferences are common knowledge is a coordination failure where the first player's optimal strategy is a zero transfer as she anticipates that the purely self-regarding second player would not return anything. As a consequence, the two players (trustor and trustee) are trapped into a Nash equilibrium that is Pareto dominated by solutions where both players choose a positive transfer and "trust pays" (i.e., the trustor receives 
more than she gives). These Pareto superior solutions require interpersonal trust (i.e., the first player chooses a nonzero transfer if she trusts the second player and if the latter is trustworthy) and therefore, in the trust investment game perspective, interpersonal trust has a positive and significant effect on the final payoffs of the game. The empirical literature of the trust investment game has shown that players choose nonzero positive transfers and their transfers (and therefore interpersonal trust) are affected by several drivers, such as strategic altruism, pure altruism, inequity aversion, risk aversion, betrayal aversion $[2,4]$ and guilt aversion for the trustor, while pure altruism [5], inequity aversion, guilt aversion, and reciprocity affect the trustee, if we limit our analysis to the one shot versions of the trust game (for a meta-experiment collecting a large number of experimental results of this literature see [6]).

Several reasons lead to the conclusion that social dilemmas such as the trust game mimic what happens in social and business relationships and that interpersonal trust is crucial, exactly as in trust games, in these relationships to produce cooperation and superior economic outcomes. Kenneth Arrow (1974) [7] argues that trust is "an important lubricant of the social system It is extremely efficient; it saves a lot of trouble to have a fair degree of reliance on other people's word. Unfortunately this is not a commodity which can be bought very easily" [7] p. 22. Knack and Keefer (1997) [8] document a positive link between trust and per capita GDP at a cross-sectional country level. Becchetti and Pace (2006) [9] and Fullenkamp and Chami (2002) [10] find a positive relation among trust, trustworthiness, and firm productivity. Guiso et al. (2009) [11] find that trust has a positive effect on financial development and foreign trade (i.e., intercountry trust has a significant effect on bilateral trade relationships). Alesina and La Ferara (2005) [12] and Montalvo and Reynal-Querol (2005) [13] illustrate how trust affects interethnic economic relationships and therefore economic performance. Becchetti and Conzo (2011) [14] demonstrate in a trust game experiment that creditworthiness is a signal of trustworthiness. They show that in a Buenos Aires suburb, trustors give significantly more to microfinance members than to nonmembers, anticipating that the former are more trustworthy since, by being members, they have been evaluated as trustworthy by a lending institution. In this way, loan concession by microfinance lenders generates a virtuous circle by which the "prophecy" of a borrower's solvency can be self-fulfilling.

In our paper we transform these considerations into a research hypothesis. We argue that business relationships have characteristics akin to those of trust investment games. Hence, in geographical areas with lower interpersonal trust, lenders anticipate that potential borrowers have a lower probability to escape coordination failures such as those of the trust investment game Nash equilibrium. By anticipating that this makes them riskier, lenders will charge higher costs when lending to borrowers in areas with lower interpersonal trust.

The literature on the relationship between social capital, financing cost and risk has been developed mainly with a focus on large banks and companies in the US and on microfinance and small borrowers in developing countries. Jin et al. [15] show that the effect of the 2007-2010 financial crisis was milder in high social capital regions. Jin et al. [16] find from US data that social capital is negatively related to changes in non-performing loans or loan loss provision, finding support for the hypothesis of a positive correlation between social capital and loan risk. Hasan et al. [17] have shown that social capital, measured with the percentage of voters in US counties, has a statistically significant and negative effect on the cost of loans. Gupta et al. [18] find that firms headquartered in US states with higher social capital have a lower cost of equity. Javakhadze et al. [19] find that social capital reduces a firm's dependence on external finance by negatively affecting the relationship between investment and cash flow. The channel postulated for interpreting the nexus between social capital and loan cost is not the only one considered in the literature. Huang and Shang [20] argue that high social capital regions have individuals who are more trustworthy and cooperative, and that therefore managers from these regions are less likely to take value-destroying actions. Jah and Cox [21] find that corporate social responsibility is positively correlated with social capital in the region where a company is 
headquartered and, as is well known, corporate social responsibility reduces exposure to ESG (stakeholder) risk. These two papers therefore identify additional channels through which local social capital can affect borrower's risk and the cost of loans.

Closer to our channel, Fogel et al. [22] find that the social capital of the CFO is associated with loans with lower spreads and fewer covenants, leading to contracting benefits beyond the impact of direct links between borrowers and lenders. However, they conceive social capital as the privileged position of the CFO in a network of business relationships that gives her an informational advantage and reduces informational asymmetries. However, they also use local social capital (number of local organizations and local network size) as control variables and find that these variables have in turn negative and significant effects.

The literature in developing countries focuses on the impact of social capital on loan repayment in formal and informal financial institutions, finding a generally positive and significant effect between social ties and repayment rates (see [23,24] among others) that parallels what was found in the US regarding large borrowers and financial institutions.

Our work innovates with respect to this fundamental contribution by looking at European countries and by using a measure of social capital, namely interpersonal trust, that better represents (as outlined in the section that follows) our theoretical assumption regarding economic life, which is that it is made of social dilemmas and has features of trust investment games. In addition to this, and as mentioned above, we jointly evaluate the impact of two dimensions of social capital by verifying whether the importance of interpersonal trust is robust when controlling for the role of trust in the legal system, an important factor, since more efficient legal institutions are correlated with better financial and economic outcomes $[25,26]$.

Our empirical findings do not reject our research hypothesis, showing that domestic interpersonal trust has a significant and negative effect on the cost of loans, interpersonal trust being a net of the impact of all relevant concurring factors such as borrower and loan characteristics and fixed effects. Among these, we include trust in the legal system, which is both another dimension of trust and a proxy of the quality of the legal system that is expected to have a significant impact on lending risk (i.e., it affects the expected length of civil controversies between lenders and borrowers and the expected value of borrowers collateral in case of default). However, consistently with what we observe in our empirical findings, in the logic of the trust investment game (our theoretical benchmark), trust in the legal system does not eliminate the importance of interpersonal trust since a large part of social and business relationships occur in "grey areas" where violation of trust is not covered by legal contracts and therefore cannot be sanctioned.

\section{Theoretical Benchmark}

For the sake of simplicity, and without a lack of generality, we assume that the outcome of the borrower's investment project is the result of a two-player trust game process where the borrower plays the role of trustor and the borrower's business partner the role of trustee. This means that, in order to produce her business outcome, the borrower interacts with another player with non-overlapping competences in a framework of asymmetrical information and incomplete contracts. The trustee is therefore intended to be a business partner whose skills and cooperation contribute significantly to the outcome of the project. As in the standard trust game, this second player may decide to reciprocate or not when she receives the contribution from the first player (the borrowing trustor). The superadditivity factor of the trust game implies that the contribution of the borrowing trustor is multiplied by 3 when it is sent to the second player. The logic is that the combination of competences triggered by the trustor's contribution creates added value because of complementarities and economies of scale in the combination of the two players' skills.

Following the standard parameters of a trust investment game [3], the borrower (trustor) payoff is $\omega_{1}-\mathrm{x}+\mathrm{y}$, while the business partner (trustee) payoff is $\omega_{2}+3 \mathrm{x}-\mathrm{y}$, 
where $\mathrm{x}(\mathrm{y})$ is the trustor's (trustee's) contribution, $\omega_{\mathrm{i}} \mathrm{i}=1$, 2 stands for the $\mathrm{i}$-th player's endowment and $\omega_{1}=\omega_{2}$.

We assume the investment is bank financed and that $\omega_{1}+\pi>D>\omega_{1}$, where $D$ is the cost of loan including interest payments, $\pi=\alpha(x * 3)-\omega_{1}$, with $\alpha$ between $\in[0,1]$ being the share of trustor contribution that the trustee gives back to the trustor and $\pi$ the borrower's total profit from the trust game. This condition implies that the loan can be repaid only if the trust game between the borrower and her partner produces a gain not lower than $\pi$ (a necessary condition for that is that the trustor giving is nonzero and trust "pays", or $y \geq x)$. Note that, as a consequence, under the Nash equilibrium of the game $(0,0)$, the debt is never repaid.

We assume that, in areas with higher interpersonal trust, $\mathrm{x}$ and $\mathrm{y}$ are higher and trust pays $(y \geq x)$. To make it simple, we assume that $p_{y}(y>x)$ is higher in areas of higher interpersonal trust. This could be explained by lenders' perceived risks and benefits associated with borrowers' opportunistic behaviors against debt holders [17,27]. Indeed, previous literature provides empirical evidence that individuals in communities with higher levels of social capital are less likely to engage in opportunistic or egoistic behaviors [28,29]. Lenders could therefore perceive firms as more trustworthy and place greater trust in those firms located in areas with higher levels of social capital [30,31]. This implies that the probability that the loan will be repaid is higher and the borrower's risk is lower for the bank in areas with higher interpersonal trust. The trust investment game has partial legal protection.

Assume now that the following socially optimal cooperative equilibrium $\left(\omega_{1}, 2 \omega_{1}\right)$ leads to a payoff of $2 \omega_{1}$ for each player, and a Pareto superior to the Nash Equilibrium $(0,0)$ is imposed by legal contract, and deviation from it can be successfully prosecuted with probability $\mathrm{p}_{\mathrm{p}}$. (In an alternative, we may assume that prosecution is fully effective but only a part $\mathrm{p}_{\mathrm{p}}<1$ of trustee's action affecting its contribution y can be regulated by contracts. Results are equivalent.) We assume that, in the case of successful prosecution, the trustee loses all her payoff.

Hence the trustee's payoff, conditional to her giving less than what fixed contractually, becomes

$$
\left(4-p_{p}\right)\left[3 \omega_{1}-y\right] \mid y<2 w_{1}
$$

while, when not breaching the contract, the trustee's payoff is

$$
3 \omega_{1}-y \mid y \geq 2 \omega_{1}
$$

We conveniently assume that, the higher the quality of the legal system, the higher players' trust in it, and therefore the value of $p_{p}$, will be. Under this framework, it is clear that both interpersonal trust and trust in the legal system contribute to the final trust game payoff.

In Figure 1, we present a case where $p_{p}$ is low and the optimal strategy for the trustee with purely self-regarding preferences (i.e., maximizing her own payoff) is still $y=0$, unless she has other-regarding preferences (i.e., inequity aversion, altruism, reciprocity). If this is the case, we assume that the borrower acting as a trustor in the trust investment game may anticipate it and choose $x \neq 0$. Hence, interpersonal trust is required in addition to legal contracts to enforce the socially optimal outcome that ensures loan repayment from the borrower. In Figure 2, the legal system is strong enough to enforce the socially optimal outcome and interpersonal trust is not required. 


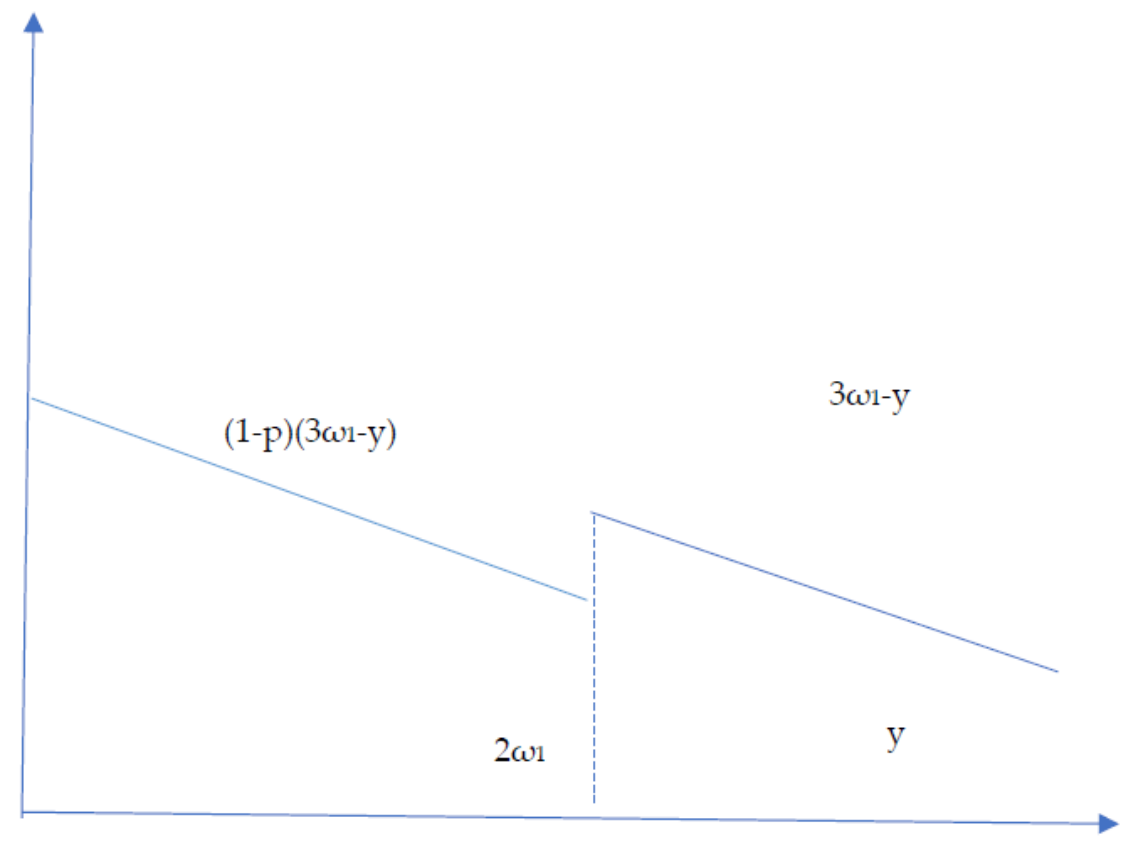

Horizontal axis: trustee's contribution. Vertical axis: trustee's payoff

(a)

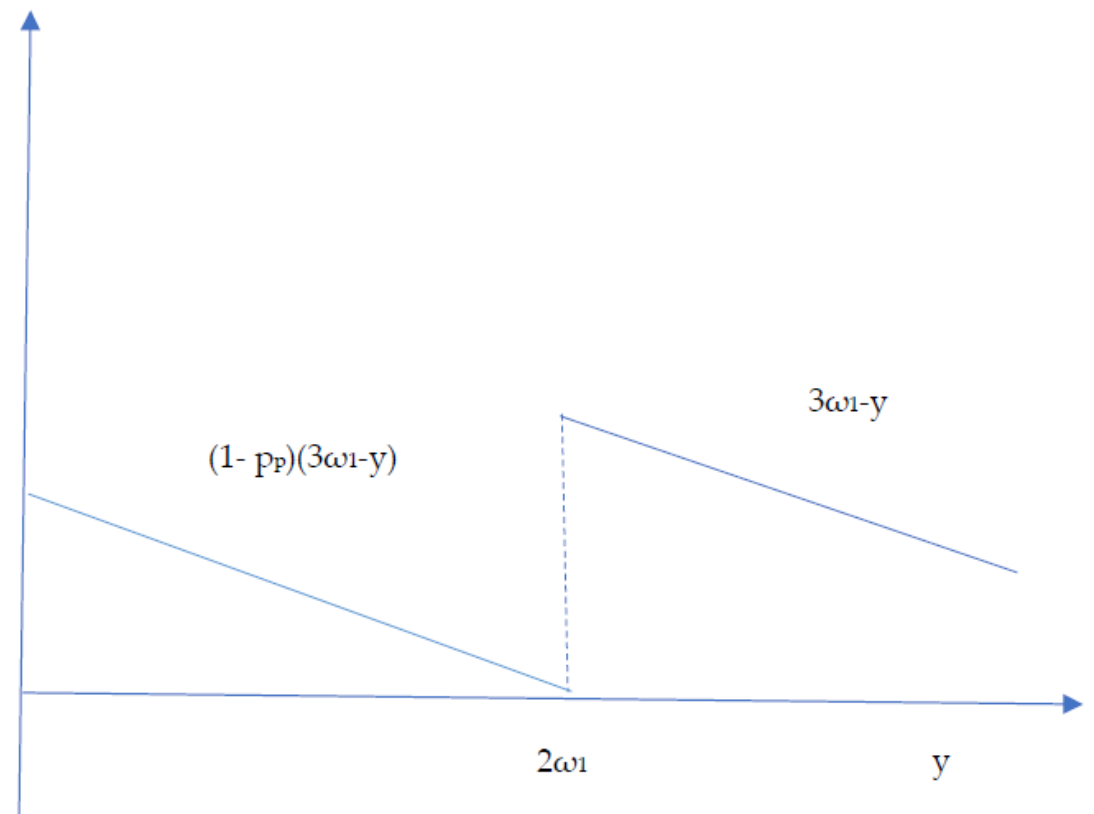

Horizontal axis: trustee's contribution. Vertical axis: trustee's payoff

(b)

Figure 1. (a) Trustee's payoff in the trust investment game (low enforcing capacity of the legal system). (b) Trustee's payoff in the trust investment game (high enforcing capacity of the legal system). 


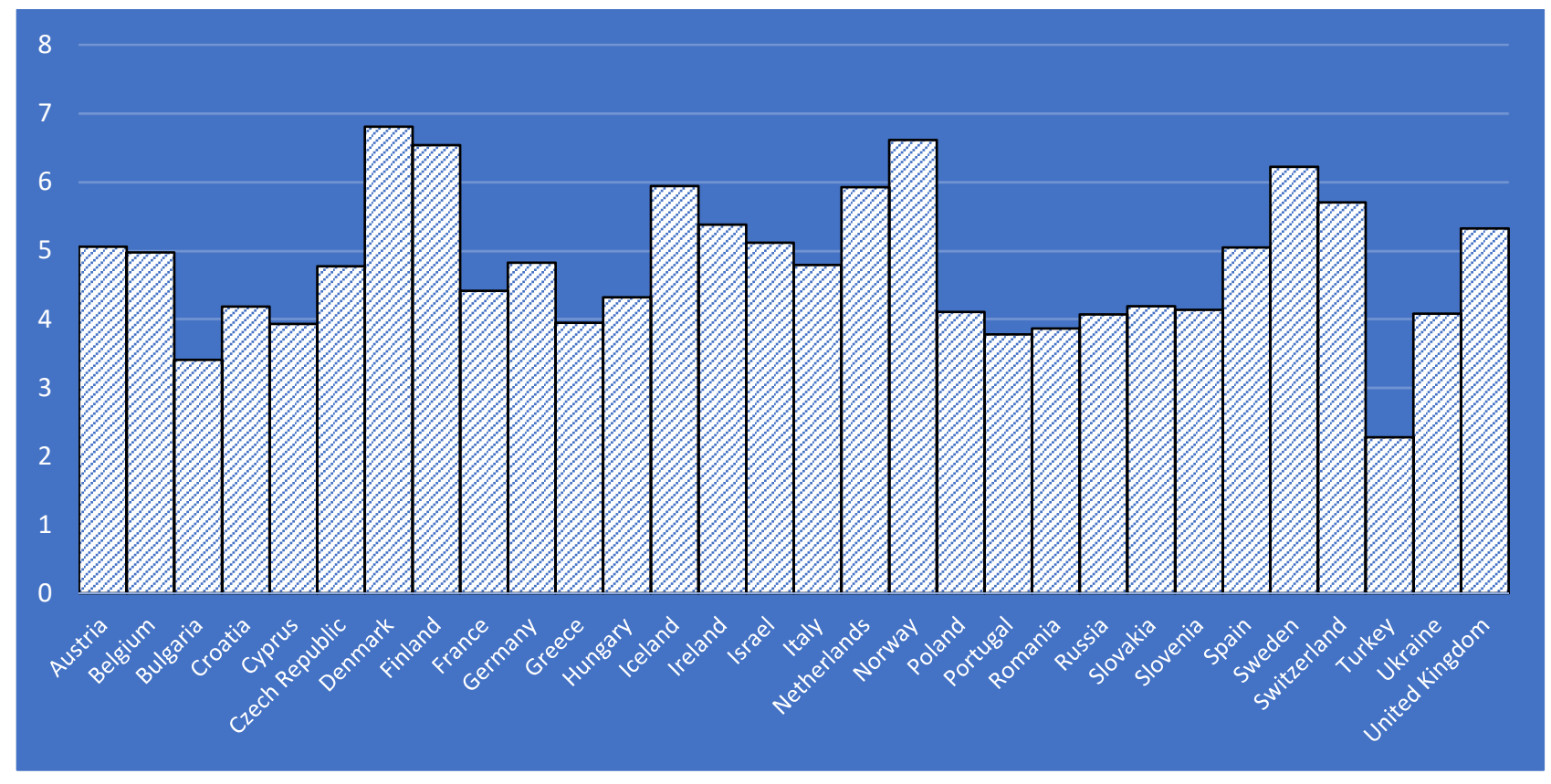

Figure 2. Population trust across borrower countries.

Figure $1 \mathrm{a}, \mathrm{b}$ therefore show that only with more efficient legal systems reducing contract incompleteness and with strong legal enforcement power (Figure 1b) is it possible to depart from the suboptimal Nash equilibrium. On the contrary, in the presence of legal system inefficiency and contract incompleteness, interpersonal trust remains crucial to producing high business outcomes and therefore to reducing the risk of business partners. The implications of this theoretical point will be drawn when formulating the two research hypotheses that follow.

\section{Research Hypothesis}

Hypothesis 1 (H1). Living in areas with higher interpersonal trust reduces borrower's cost of loan.

If business relationships have the characteristics of the social dilemma described in the trust investment game [3], lenders anticipate that borrowers living in regions where interpersonal trust is higher are less risky in the sense that they are more likely to develop successful business relationships. By the logic of the model developed in the previous section, higher interpersonal trust raises the probability that players find cooperative equilibria, generating payoffs that can repay debt financed investment.

The maintained assumption of our hypothesis is that the four main features of the investment trust game apply. More specifically, (i) business relationships occur in a framework of asymmetrical information, where it is impossible to forecast without error the future behavior of business partners; (ii) legal contracts are incomplete, so that many contingencies of business relationships are not covered by contract clauses and therefore abuses of trust in these contingencies cannot be prosecuted; (iii) business partners have non-overlapping competences, so that they need each other to improve their business, and therefore lack of cooperation, preventing the matching of competences, significantly reduces the final outcome; and (iv) cooperation has superadditive effects, that is, its result is superior to the sum of the stand-alone business partners' outcomes. In this situation higher average trust and trustworthiness in the geographical area in which the borrower lives is crucial to depart from the low-output socially inefficient Nash equilibrium. Living in a high interpersonal trust environment in fact reduces the probability of finding low trust or low trustworthiness in a match between business partners and therefore reduces the risk of low outcomes in business relationships. 
We assume that the lender has this model in mind (or develops an intuition that broadly corresponds to it and its outcomes) and therefore evaluates that the borrower living in a high interpersonal capital environment has a lower probability of low output in its business relationship and therefore lower lending risk.

Hypothesis 2 (H2). The significant effect of interpersonal trust occurs net of the effect of trust in the legal system.

If, together with the other three conditions stated in hyphen $H_{0}$ the maintained assumption (ii) of the previous research hypothesis holds (incomplete contracts), or if enforcement of legal contracts and sanctions related to its violation are imperfect, interpersonal trust plays a role even after controlling for trust in the legal system (Figure 1a). This is because, in the logic of the trust investment game, interpersonal trust is crucial for the creation of value in those "grey areas" where there is no coverage of legal contracts, as is the case in most social and economic interactions and in the trust investment games played in the labs.

\section{Data Sources}

In order to test our hypothesis, we extract information from three different datasets. Our measure of trust comes from a question of the European Social Survey (ESS), a crossnational survey conducted every two years in the European Union since 2001 measuring attitudes and beliefs in European countries together with standard socio-economic characteristics. More specifically, our measure of trust in a given country comes from the question having the following extremes: "Most people can be trusted" and "you can't be too careful", where respondents are asked to give a grade going from a minimum value of 1 ("you can't") to a maximum value of 10 ("Most people").

The external validity of this measure of trust has been widely discussed in the literature given its extensive use. In particular, Gleaser [32] questions the validity of the World Values Survey (from now on WVS) trust measure by arguing that it is not correlated with senders' behavior in the standard trust game. On the other side, Fehr et al. [33] find the opposite result: WVS measures of trust are correlated with sender behavior, but not with their trustworthiness. Guiso et al. [34] provide an answer to the puzzle, claiming that the WVS question is able to capture the belief-based component of trust and is a good measure of the expectation component of trust in economically relevant situations. We therefore conclude that this variable is the best proxy to verify our research hypothesis formulated on the basis of the trust investment game theoretical benchmark. More specifically, and consistently with the conclusions of Guiso et al. [34], we assume that lenders are aware of the interpersonal trust of a given region proxied by the WVS measure, and formulate based on that their beliefs regarding the probability that the borrower will achieve cooperative equilibria with their business partner, generating outcomes that can repay the debt.

Information on loans is retrieved by the Dealscan database. The dataset is widely used in the banking literature and contains detailed information on syndicated loan pricing and characteristics of both borrowers and lenders. Our basic unit of observation is the credit facility. Each loan package includes several facilities that are different for their purpose and type. Most of them are standard credit lines (almost half of the sample) or term loans. Last, information on firm and bank characteristics have been downloaded from Compustat. The dependent variable we use in the econometric analysis that follows comes from this database and is the All-in Spread Drawn that is the amount paid in bps over LIBOR for each dollar drawn.

Our final dataset includes 4571 credit facility observations and information on 1261 firms that issued at least a syndicated loan in the period spanning 2005 to 2016. In Table 1, we report the main variables relevant to our empirical analysis that are included in our merged dataset. Table 2 reports the country distribution of our sample. 
Table 1. Variable legend. This table reports the variables included in the dataset. In particular, Panel A reports loan characteristic variables. Panel B reports firms' characteristic variables. Panel C reports trust related variables. These variables belong to two different datasets: European Social Survey and Compustat.

\begin{tabular}{|c|c|}
\hline \multicolumn{2}{|r|}{ Panel A: Loan Characteristics } \\
\hline Variable Name & Definition \\
\hline All-in Spread Drawn & Amount paid in bps over LIBOR for each dollar drawn \\
\hline Log (All-in Spread Drawn) & Logarithm of the variable "All-in drawn" \\
\hline Facility amount & Amount of the facility in dollars \\
\hline Maturity & Number of months the facility will be active since the starting date \\
\hline Purpose of the Loan & $\begin{array}{l}\text { Main purpose of the facility (Acquisition Line, Aircraft finance, CP backup, Capital expenditures, } \\
\text { Corporate Purposes, Debt Repayment, Defensive bid, Exit financing, Guarantee, IPO, Merger, Real } \\
\text { estate, Recap., Restructuring, Securities Purchase, Ship finance, Spinoff, Stock Buyback, Takeover, } \\
\text { Trade Finance, Work. Cap.) }\end{array}$ \\
\hline Country of syndication & $\begin{array}{l}\text { Country in which the loan has been syndicated (Australia, Austria, Belgium, Bermuda, Brazil, } \\
\text { Canada, Chad, Chile, China, Czech Republic, Denmark, Dominican Republic, Egypt, Finland, France, } \\
\text { Germany, Ghana, Greece, Hong Kong, India, Ireland, Israel, Italy, Japan, Jordan, Kazakhstan, } \\
\text { Korea (South), Liberia, Luxembourg, Mexico, Mongolia, Netherlands, New Zealand, Norway, Peru, } \\
\text { Philippines, Poland, Portugal, Qatar, Russia, Singapore, South Africa, Spain, Sweden, Switzerland, } \\
\text { Taiwan, Thailand, Turkey, USA, United Arab Emirates, United Kingdom, Uzbekistan.) }\end{array}$ \\
\hline \multicolumn{2}{|r|}{ Panel B: Firm Characteristics } \\
\hline Variable Name & Definition \\
\hline Company & Company name \\
\hline Country & Country of the company headquarters (See Table 2) \\
\hline Industry & Industry in which the firm operates according to the two digits of the SIC code \\
\hline Leverage & Ratio of Total Debt over Total Capital \\
\hline Return on Investment & Return on Investment \\
\hline Cash/Total Capital & Proportion of Cash over Total Capital \\
\hline Total Assets & Total Assets of the company \\
\hline \multicolumn{2}{|r|}{ Panel C: Trust and Country Variables } \\
\hline Variable Name & Definition \\
\hline Interpersonal Trust & $\begin{array}{l}\text { Respondent answer ranging from "Most people can be trusted" to "you can't be too careful" where } \\
\text { respondents are asked to give a grade going from a minimum value of } 1 \text { ("you can't") until a } \\
\text { maximum value of } 10 \text { ("Most people") }\end{array}$ \\
\hline Trust in Legal System & Respondent trust on the legal system (0-10) \\
\hline Education & Percent of graduates in the area \\
\hline
\end{tabular}

Table 2. (Country Distribution).

\begin{tabular}{cccc}
\hline Country Name & Counts & Percentage & Cumulative \\
\hline Austria & 11 & 0.24 & 0.24 \\
Belgium & 64 & 1.40 & 1.64 \\
Bulgaria & 14 & 0.31 & 1.95 \\
Croatia & 1 & 0.02 & 1.97 \\
Cyprus & 9 & 0.20 & 2.17 \\
Czech Republic & 4 & 0.09 & 2.25 \\
Denmark & 56 & 1.23 & 3.48 \\
Finland & 61 & 1.33 & 4.81 \\
France & 723 & 15.82 & 20.63 \\
Germany & 586 & 12.82 & 33.45 \\
Greece & 3 & 0.07 & 33.52 \\
\hline
\end{tabular}


Table 2. Cont.

\begin{tabular}{cccc}
\hline Country Name & Counts & Percentage & Cumulative \\
\hline Hungary & 19 & 0.42 & 33.93 \\
Iceland & 5 & 0.11 & 34.04 \\
Ireland & 77 & 1.68 & 35.73 \\
Israel & 16 & 0.35 & 36.08 \\
Italy & 34 & 0.74 & 36.82 \\
Netherlands & 339 & 7.42 & 44.24 \\
Norway & 120 & 2.63 & 46.86 \\
Poland & 29 & 0.63 & 47.50 \\
Portugal & 40 & 0.88 & 48.37 \\
Romania & 4 & 0.09 & 48.46 \\
Russia & 240 & 5.25 & 53.71 \\
Slovakia & 5 & 0.11 & 53.82 \\
Slovenia & 12 & 0.26 & 54.08 \\
Spain & 416 & 9.10 & 63.18 \\
Sweden & 160 & 3.50 & 66.68 \\
Switzerland & 166 & 3.63 & 70.31 \\
Turkey & 41 & 0.90 & 71.21 \\
Ukraine & 34 & 0.74 & 71.95 \\
United Kingdom & 1282 & 28.05 & 100.00 \\
Total & 4571 & & 100.0 \\
\hline
\end{tabular}

\section{Descriptive Statistics}

Summary statistics are reported in Table 3. Our variable of interest, interpersonal trust, is on average equal to 5.09 , ranging from a minimum of 2.72 (Turkey) to a maximum of 6.80 (Denmark). Average population trust by country is reported in Figure 2. Our measure of loan cost, the "All-in Spread Drawn", is on average equal to $205 \mathrm{bps}$. It is measured considering one hundred percent usage of the credit facility and is quoted over LIBOR. Maturity is expressed in months and is on average equal to 60 months. The facility amount and total assets are expressed in millions of dollars and their mean values are respectively equal to 1055.60 and 37,702 . Borrowers' balance sheet summary statistics are also reported in Table 3. The mean return on investment is around 10 percent, the proportion of cash over total assets is on average equal to 0.22 , and the proportion of debt over total capital is on average equal to 0.77 .

Table 3. Descriptive statistics.

\begin{tabular}{|c|c|c|c|c|c|c|}
\hline & Count & Mean & SD & 25th Percentile & 50th Percentile & 75th Percentile \\
\hline All-in Drawn & 4571 & 203.86 & 175.68 & 70 & 175 & 275 \\
\hline Maturity & 4571 & 60.64 & 38.87 & 36 & 60 & 72 \\
\hline Interpersonal Trust & 4571 & 5.09 & 0.72 & 4.57 & 5.14 & 5.35 \\
\hline Facility amount (Millions of \$) & 4571 & 1055.60 & 2141.50 & 110.66 & 352.39 & 1100 \\
\hline Total Assets (Millions of \$) & 4305 & 37,702 & $88,415.44$ & 1328.52 & 4936.64 & $28,517.26$ \\
\hline ROI & 4544 & 0.10 & 0.07 & 0.06 & 0.09 & 0.13 \\
\hline Cash/Total Capital & 3907 & 0.22 & 0.15 & 0.11 & 0.19 & 0.29 \\
\hline Leverage & 4554 & 0.69 & 0.26 & 0.55 & 0.69 & 0.83 \\
\hline Education ( $\%$ of graduates) & 4281 & 27.31 & 5.10 & 24.4 & 27.6 & 30 \\
\hline Trust in legal system & 4571 & 5.28 & 0.83 & 5.00 & 5.21 & 5.75 \\
\hline
\end{tabular}




\section{Econometric Analysis}

In order to test our research hypothesis, we estimate the following specification:

$$
\begin{aligned}
\log (\text { All }- \text { in Spread })_{i, t} & =\alpha+\beta_{1} \ln (\text { Interpersonal_Trust })_{i, t}+\beta_{2} \ln (\text { Trust_on_Legal_Institutions })_{i, t} \\
& +\sum_{j=1}^{n(\gamma)} \gamma_{j} \text { Firm Characteristics } j i, t_{j}+\sum_{h=1}^{n(h)} \delta_{h} \text { DLoan Type }_{h}+\sum_{l=1}^{n(l)} \vartheta_{l} \text { DLoan }_{\text {Purpose }} \\
& +\sum_{m=1}^{n(m)} \zeta_{m} \text { DCountry of Sindication }_{m}+\sum_{p=1}^{n(p)} \eta_{p} \text { DCountry }_{p}+\sum_{r=1}^{n(r)} \lambda_{r} \text { DIndustry }_{r} \\
& +\sum_{s=1}^{n(s)} \xi_{s} \text { DYear }_{s}+\varepsilon_{i, t}
\end{aligned}
$$

where our dependent variable is, the comprehensive measure of the cost of lending represented by the all-in spread drawn.

Our key regressor (Interpersonal_Trust) is the average WVS (World Value Survey) measure of interpersonal trust for the given country-year described in Section 4. Our controls include average self-declared trust in the legal system for the considered countryyear available in the European Social Survey (Trust_on_Legal_System) and a list of variables measuring firm and loan characteristics. Among firm characteristics, we include return on investment, cash/total assets, leverage (total liabilities/total assets), and total assets as a proxy of size. For what concerns loan characteristics, we control for loan maturity and for the facility amount, which are crucial drivers of the bank loan cost. We also control for the heterogeneity in loan types (controlling for the breakdown of loan and lender characteristics as described in the variable legend of Table 1) and the share of individuals with a university degree in the country.

Following the standard approach in the empirical literature of using DealScan data (see among others Fields et al. 2012 [35]; Hasan et al. 2014 [27] and 2017 [17]; Goss and Roberts, 2011 [36]; Graham et al. 2008 [37]) the model includes country fixed effects, year fixed effects in order to account for time-related macroeconomic shocks, and industry fixed effects using the two digits of the primary SIC code in order to control for heterogeneous industryrelated risk components affecting the loan cost. We also include lender characteristics, measured as the number of lenders taking part in the syndicated loan, as well as country of loan syndication, in order to control for the legal environment of the country where the syndicated loan is issued. We finally include borrower fixed effects, in order to control for time invariant firm characteristics of the latter.

\section{Results}

The findings presented in Table 4 show that our main variable of interest (interpersonal trust) is negative and statistically significant in each considered specification. According to coefficients estimated in our fully-augmented model, a one standard deviation increase in interpersonal trust is associated with a decrease in the bank loan cost of $48 \mathrm{bps}$. The effect of local social capital on the bank loan cost is larger with respect to the result obtained by Hasan et al. [17], which found that a standard deviation increase in social capital is associated with a decrease in the bank loan cost of $12.5 \mathrm{bps}$. A likely rationale for this difference is that, in our sample, we are comparing borrowers from all around the world. Given that cross-country variability of social capital is higher than that among US member states, one standard deviation increase in social capital is expected to affect the cost of credit more. 
Table 4. The effect of interpersonal trust in all in spread drawn.

\begin{tabular}{|c|c|c|c|c|}
\hline & (1) & (2) & (3) & (4) \\
\hline Varıabies & OLS & OLS & OLS & OLS \\
\hline Interpersonal Trust & $\begin{array}{c}-58.61 \text { ** } \\
(24.54)\end{array}$ & $\begin{array}{c}-81.86^{* * *} \\
(25.74)\end{array}$ & $\begin{array}{c}-69.96^{* * *} \\
(25.38)\end{array}$ & $\begin{array}{c}-68.91^{* *} \\
(28.18)\end{array}$ \\
\hline Maturity & & $\begin{array}{c}0.544^{* * * *} \\
(0.119)\end{array}$ & $\begin{array}{c}0.545^{* * *} \\
(0.119)\end{array}$ & $\begin{array}{c}0.653 * * * \\
(0.120)\end{array}$ \\
\hline Log (Facility amount) & & $\begin{array}{c}-7.739 * * * \\
(2.624)\end{array}$ & $\begin{array}{c}-7.387^{* * *} \\
(2.629)\end{array}$ & $\begin{array}{c}-4.620 \text { * } \\
(2.384)\end{array}$ \\
\hline Log (Total Assets) & & $\begin{array}{l}-8.617 \\
(6.329)\end{array}$ & $\begin{array}{c}-11.49 * \\
(6.464)\end{array}$ & $\begin{array}{c}-25.30 \\
(10.92)\end{array}$ \\
\hline ROI & & $\begin{array}{c}-338.9^{* * *} \\
(90.93)\end{array}$ & $\begin{array}{c}-327.4^{* * *} \\
(89.45)\end{array}$ & $\begin{array}{c}-298.6^{* * *} \\
(98.36)\end{array}$ \\
\hline Cash & & $\begin{array}{c}33.39 \\
(77.99)\end{array}$ & $\begin{array}{c}17.42 \\
(78.26)\end{array}$ & $\begin{array}{l}-1.924 \\
(78.67)\end{array}$ \\
\hline Leverage & & $\begin{array}{c}144.6^{* * *} \\
(40.67)\end{array}$ & $\begin{array}{c}138.0 * * * \\
(39.42)\end{array}$ & $\begin{array}{c}190.7^{* * *} \\
(44.67)\end{array}$ \\
\hline Trust in Legal System & & & $\begin{array}{c}-36.86^{* * *} \\
(10.75)\end{array}$ & $\begin{array}{c}-47.96^{* * *} \\
(10.99)\end{array}$ \\
\hline Education & & & & $\begin{array}{c}8.682 * * * \\
(2.627)\end{array}$ \\
\hline Loan type FE & YES & YES & YES & YES \\
\hline Country Of Syndication FE & YES & YES & YES & YES \\
\hline Industry FE & YES & YES & YES & YES \\
\hline Country FE & YES & YES & YES & YES \\
\hline Year FE & YES & YES & YES & YES \\
\hline Firm FE & $\mathrm{NO}$ & $\mathrm{NO}$ & $\mathrm{NO}$ & YES \\
\hline Lender FE & $\mathrm{NO}$ & $\mathrm{NO}$ & $\mathrm{NO}$ & YES \\
\hline Constant & $\begin{array}{c}295.8 * * \\
(128.7)\end{array}$ & $\begin{array}{c}607.4^{* * *} \\
(144.3)\end{array}$ & $\begin{array}{c}784.2^{* * *} \\
(163.4)\end{array}$ & $\begin{array}{l}1013^{* * *} \\
(213.8)\end{array}$ \\
\hline Observations & 4571 & 4273 & 4273 & 3893 \\
\hline R-squared & 0.443 & 0.788 & 0.789 & 0.801 \\
\hline
\end{tabular}

Robust standard errors in parentheses. ${ }^{* * *} p<0.01,{ }^{* *} p<0.05,{ }^{*} p<0.1$.

When including trust in the legal system in our fully augmented model, we find, as expected, that this variable also has beneficial effects on the cost of debt, even though its presence in the estimate does not eliminate the significance of interpersonal trust. This is consistent with our second null hypothesis as well as the second version of the model presented in our theoretical benchmark Section 2, where violations of trust are imperfectly sanctioned.

Among other controls, we find that the facility amount and firm size have a negative and statistically significant impact on bank loan cost, as has been found in previous studies (e.g., Hasan et al., 2017) [17]. Our measure of leverage (total liabilities/total assets) has, as expected, a positive and significant effect on the dependent variable, indicating higher financial risk. Profitability (return on equity) reduces such risk and therefore has a negative and significant effect on the cost of debt.

\section{Identification Strategy}

Our econometric findings indicating a significant and negative correlation between interpersonal trust and cost of debt do not eliminate per se the suspicion of an endogenous relationship where a third driver may cause both higher local interpersonal trust and lower cost of debt.

In order to overcome this problem, we follow the literature and propose as an identification strategy the use of religion as an instrument (e.g., Guiso et al., 2003) [34]. Our measure of religion also comes from the European Social Survey and measures the intensity of religious beliefs through the following question "How religious are you?". The variable 
values range from 0 for the answer "Not at all" up to a value of 10 for the answer "Very Religious". The average values for each borrower's country are shown in Figure 3.

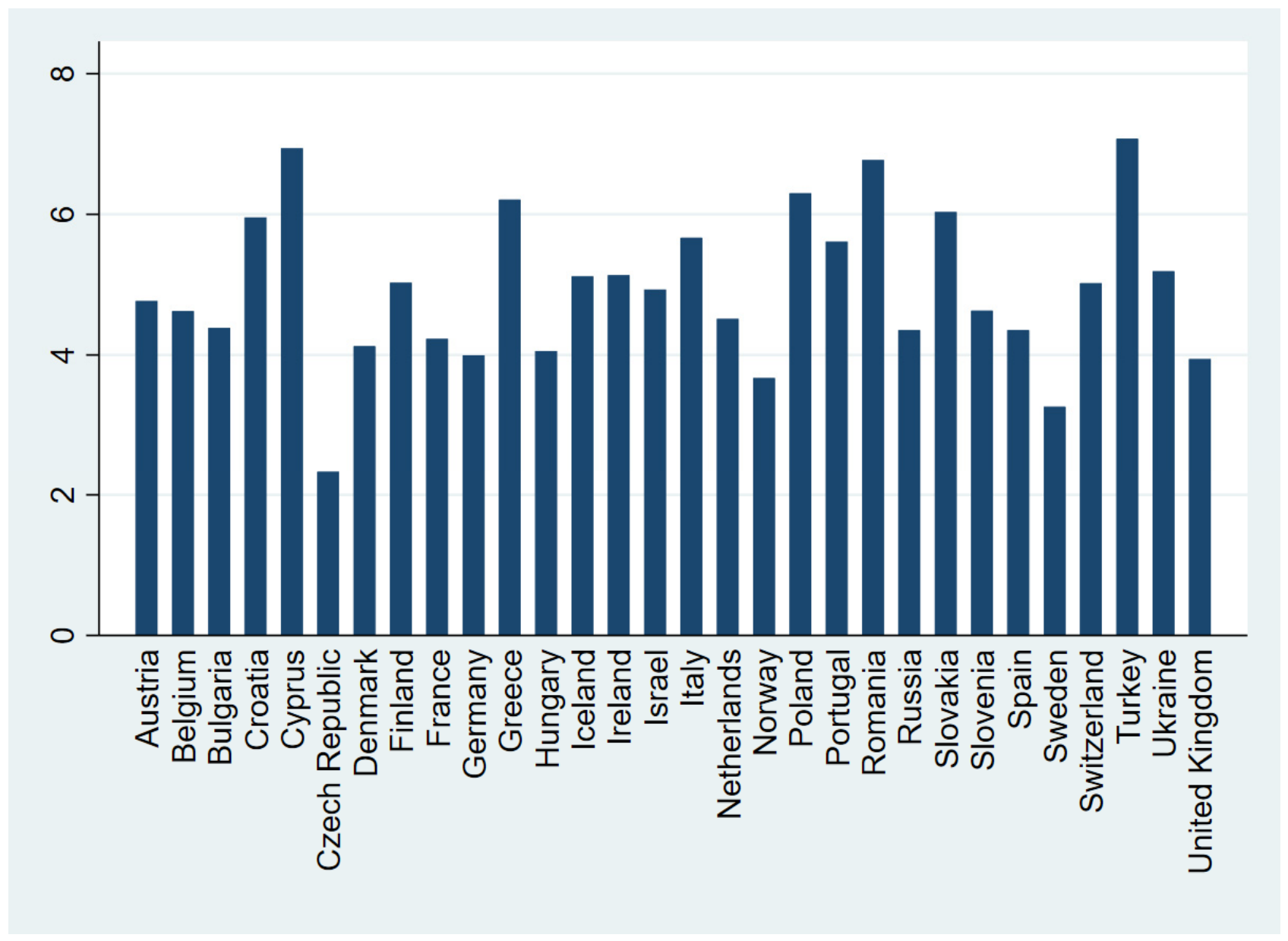

Figure 3. Religiosity across borrower countries.

Religion may definitely be considered a relevant instrument for interpersonal trust, since religious norms praise trust and blame trust betrayal, thereby contributing to the creation and reinforcement of domestic social norms against a lack of positive reciprocity and in favor of trust. In addition to this, believers have stronger moral norms that act as a deterrent for a lack of trustworthiness, increasing the disutility of a lack of positive reciprocity. We talk about positive reciprocity since religions (especially the Christian one) are also against negative reciprocity, as in the famous "cheek" saying (if someone slaps you on one cheek, turn to them the other also). Religion can also be considered a valid instrument since there is no reason to expect that the intensity of religious beliefs in a country affects per se the corporate cost of debt. Several tests confirm the validity of our instrument. More specifically, the F-test is much higher than the well-known critical value of 10 and is also higher than the value suggested by [35], confirming the hypothesis that our instrument is strong. The Kleibergen-Paap rk LM statistics also reject the null hypothesis that the model is under-identified. Results are reported in Table 5. Again, the coefficient is still negative and statistically significant, signaling that our analysis is not affected by endogeneity. 
Table 5. Instrumental Variable (IV) estimates.

\begin{tabular}{|c|c|}
\hline Variables & IV \\
\hline Interpersonal Trust & $\begin{array}{l}-156.9^{* *} \\
(77.57)\end{array}$ \\
\hline Maturity & $\begin{array}{l}0.657^{* * * *} \\
(0.100)\end{array}$ \\
\hline Log (Facility amount) & $\begin{array}{l}-4.812 * * \\
(1.996)\end{array}$ \\
\hline Log (Total Assets) & $\begin{array}{l}-25.10 * * * \\
(9.158)\end{array}$ \\
\hline ROI & $\begin{array}{l}-292.9^{* * * *} \\
(82.83)\end{array}$ \\
\hline Cash & $\begin{array}{c}0.419 \\
(66.04)\end{array}$ \\
\hline Leverage & $\begin{array}{c}192.9^{* * *} \\
(36.97)\end{array}$ \\
\hline Trust in Legal System & $\begin{array}{c}-36.97^{* * *} \\
(13.89)\end{array}$ \\
\hline Education & $\begin{array}{l}6.324^{* *} \\
(2.987)\end{array}$ \\
\hline Loan type FE & YES \\
\hline Country Of Syndication FE & YES \\
\hline Industry FE & YES \\
\hline Country FE & YES \\
\hline Year FE & YES \\
\hline Firm FE & YES \\
\hline Lender FE & YES \\
\hline Constant & $\begin{array}{l}1428^{* * *} \\
(383.9)\end{array}$ \\
\hline Kleibergen-Paap rk LM statistic & $\begin{array}{c}\text { Chi-sq }(1)=121.995 \\
p \text {-value }=0.00\end{array}$ \\
\hline F test on excluded instrument & 222.18 \\
\hline Observations & 3893 \\
\hline R-squared & 0.800 \\
\hline
\end{tabular}

\section{Conclusions}

There is a growing consensus in the economic literature on the role of trust and trustworthiness as the main pillars of social capital, as well as on the fact that social capital is one of the most important factors in ensuring the success of economic activity at the individual and aggregate levels. If trust and trustworthiness are so important for entrepreneurial success, they should also be taken into account by rational lenders when evaluating risk and the probability of success of screened would-be borrowers.

Based on this intuition, we outline in the paper a theoretical benchmark assuming that business relationships have the standard features of investment trust games, that is, they occur in a framework of asymmetric information, incomplete contracts, and nonoverlapping competences. In such a framework, bank financed investors should pay higher costs for loans in areas where social capital is lower and where, therefore, the probability of having business partners with lower levels of reciprocal trust is higher.

Our econometric findings do not reject our research hypothesis, showing that the cost of loans is significantly lower where interpersonal trust is higher, which is a net result of the impact of a wide range of controls, including loan type and purpose, borrower characteristics, country of syndication and industry, borrower, country, and year effects. Econometric results are robust in the face of endogeneity concerns when using an instrumental variable (IV) approach. 
Our findings identify in the literature an additional channel regarding the effect of social capital on economic activity that reinforces the positive nexus between the two variables. They show that social capital positively affects this not only directly but also indirectly via the higher cost of loans when investment is bank-financed. Our findings suggest at least two plausible policy implications: policies aiming to develop social capital (i.e., social capital accelerators) could have the additional positive effect of reducing the cost of external finance for local investors, and bank regulators should take into account social capital as a factor reducing lending risk when defining correcting factors for bank reserve requirements. The regulators could take into account the nexus between social capital and borrower risk by calculating the average levels of interpersonal trust in the geographical area in which the borrower conducts their business (i.e., for European countries, NUTS2 average values of interpersonal trust are available in survey data from the European Social Survey). In this respect, they could make reference to an index weighted for the geographical shares of activity based on a geographical breakdown of the borrower's net sales. Overlaps and redundancies with other country risk indicators that are correlated with interpersonal trust should be avoided.

Author Contributions: Conceptualization, L.B. and F.P.; methodology, S.M.; software, S.M. and F.P.; formal analysis, S.M.; investigation, L.B., S.M. and F.P.; data curation, F.P.; writing-Leonardo Bechetti.; writing-review and editing, S.M. and F.P.; visualization, F.P. All authors have read and agreed to the published version of the manuscript.

Funding: This research received no external funding.

Data Availability Statement: Restrictions apply to the availability of these data. Data was obtained from Wharton Research Data Services and are available with the permission from Thomson Reuters LPC's LoanConnector.

Conflicts of Interest: The authors declare no conflict of interest.

\section{References}

1. Hong, K.; Bohnet, I. Status and distrust: The relevance of inequality and betrayal aversion. J. Econ. Psychol. 2007, 28, 197-213. [CrossRef]

2. Fehr, E. On the economics and biology of trust. J. Eur. Econ. Assoc. 2009, 7, 235-266. [CrossRef]

3. Berg, J.; Dickaut, J.; McCabe, K. Trust, reciprocity and social history. Games Econ. Behav. 1995, 10, 122-142. [CrossRef]

4. Bohnet, I.; Greig, F.; Herrmann, B.; Zeckhauser, R. Betrayal aversion: Evidence from Brazil, China, Oman, Switzerland, Turkey, and the United States. Am. Econ. Rev. 2008, 98, 294-310. [CrossRef]

5. Cox, J.C. How to identify trust and reciprocity. Games Econ. Behav. 2004, 46, 260-281. [CrossRef]

6. Johnson, N.D.; Mislin, A. Trust games: A meta-analysis. J. Econ. Psychol. 2011, 32, 865-889. [CrossRef]

7. Arrow, K. The Limits of Organisation; Norton \& Company: New York, NY, USA, 1974.

8. Knack, S.; Keefer, P. Does social capital have an economic payoff? A cross-country investigation. Q. J. Econ. 1997, 112, 1251-1288. [CrossRef]

9. Becchetti, L.; Pace, N. The Valorisation of Human Capital as a Key Element of Competitiveness. The "Trust Game Corporation" Perspective; Fondazione Eni Enrico Mattei: Milano, Italy, 2006.

10. Chami, R.; Fullenkamp, C. Trust and efficiency. J. Bank. Financ. 2002, 26, 1785-1809. [CrossRef]

11. Guiso, L.; Sapienza, P.; Zingales, L. Cultural biases in Economic Exchange? Q. J. Econ. 2009, 124, 1095-1131. [CrossRef]

12. Alesina, A.; La Ferrara, E. Ethnic Diversity and Economic Performance. J. Econ. Lit. 2005, 43, 762-800. [CrossRef]

13. Montalvo, G.; Reynal-Querol, M. Ethnic Diversity and Economic Development. J. Dev. Econ. 2005, 76, 293-323. [CrossRef]

14. Becchetti, L.; Conzo, P. Creditworthiness as a signal of trustworthiness. J. Public Econ. 2011, 95, 265-278. [CrossRef]

15. Jin, J.Y.; Kanagaretnam, K.; Lobo, G.J.; Mathieu, R. Social capital and bank stability. J. Financ. Stab. 2017, 32, 99-114. [CrossRef]

16. Jin, J.Y.; Kanagaretnam, K.; Liu, Y.; Liu, N. Banks' loan growth, loan quality, and social capital. J. Behav. Exp. Financ. 2019, 21, 83-102. [CrossRef]

17. Hasan, I.; Hoi, C.K.; Wu, Q.; Zhang, H. Social capital and debt contracting: Evidence from bank loans and public bonds. J. Financ. Quant. Anal. 2017, 52, 1017-1047. [CrossRef]

18. Gupta, A.; Raman, K.; Shang, C. Social capital and the cost of equity. J. Bank. Financ. 2018, 87, 102-117. [CrossRef]

19. Javakhadze, D.; Ferris, S.P.; French, D.W. Social capital, investments, and external financing. J. Corp. Financ. 2016, 37, 38-55. [CrossRef]

20. Huang, K.; Shang, C. Leverage, debt maturity, and social capital. J. Corp. Financ. 2019, 54, 26-46. [CrossRef]

21. Jha, A.; Cox, J. Corporate social responsibility and social capital. J. Bank. Financ. 2015, 60, 252-270. [CrossRef] 
22. Fogel, K.; Jandik, T.; McCumber, W.R. CFO social capital and private debt. J. Corp. Financ. 2018, 52, 28-52. [CrossRef]

23. Cassar, A.; Crowley, L.; Wydick, B. The effect of social capital on group loan repayment: Evidence from field experiments. Econ. J. 2007, 117, F85-F106. [CrossRef]

24. Dufhues, T.; Buchenrieder, G.; Quoc, H.D.; Munkung, N. Social capital and loan repayment performance in Southeast Asia. J. Soc. Econ. 2011, 40, 679-691. [CrossRef]

25. Qian, J.; Strahan, P.E. How laws and institutions shape financial contracts: The case of bank loans. J. Financ. 2007, 62, 2803-2834. [CrossRef]

26. Rajan, R.G.; Zingales, L. The great reversals: The politics of financial development in the twentieth century. J. Financ. Econ. 2003, 69, 5-50. [CrossRef]

27. Hasan, I.; Hoi CK, S.; Wu, Q.; Zhang, H. Beauty is in the eye of the beholder: The effect of corporate tax avoidance on the cost of bank loans. J. Financ. Econ. 2014, 113, 109-130. [CrossRef]

28. Posner, M.I.; Rothbart, M.K. Developing mechanisms of self-regulation. Dev. Psychopathol. 2000, 12, 427-441. [CrossRef] [PubMed]

29. Uhlaner, C.J. "Relational goods" and participation: Incorporating sociability into a theory of rational action. Public Choice 1989, 62, 253-285. [CrossRef]

30. Fukuyama, F. Trust: Human Nature and the Reconstitution of Social Order; Simon and Schuster: New York, NY, USA, 1996.

31. Guiso, L.; Sapienza, P.; Zingales, L. Does local financial development matter? Q. J. Econ. 2004, 119, 929-969. [CrossRef]

32. Glaeser, E.L.; Laibson, D.I.; Scheinkman, J.A.; Soutter, C.L. Measuring trust. Q. J. Econ. 2000, 115, 811-846. [CrossRef]

33. Fehr, E.; Fischbacher, U.; von Rosenbladt, B.; Schupp, J.; Wagner, G.G. A nation-wide laboratory: Examining trust and trustworthiness by integrating behavioral experiments into representative survey. Work. Pap. Ser. 2003. [CrossRef]

34. Guiso, L.; Sapienza, P.; Zingales, L. People's opium? Religion and economic attitudes. J. Monet. Econ. 2003, 50, 225-282. [CrossRef]

35. Fields, L.P.; Fraser, D.R.; Subrahmanyam, A. Board quality and the cost of debt capital: The case of bank loans. J. Bank. Financ. 2012, 36, 1536-1547. [CrossRef]

36. Goss, A.; Roberts, G.S. The impact of corporate social responsibility on the cost of bank loans. J. Bank. Financ. 2011, 35, 1794-1810. [CrossRef]

37. Graham, J.R.; Li, S.; Qiu, J. Corporate misreporting and bank loan contracting. J. Financ. Econ. 2008, 89, 44-61. [CrossRef] 